\title{
Yield forecasting of wheat and mustard for western Uttar Pradesh using statistical model
}

\section{SMITA GUPTA ${ }^{1}$, AJIT SINGH ${ }^{1}$, ASHOK KUMAR ${ }^{1}$, U.P.SHAHI ${ }^{1}$, NISHANT K SINHA ${ }^{2}$ and SUMANA ROY $^{3}$}

${ }^{1}$ Sardar Vallabhbhai Patel University of Agriculture \& technology Modipuram(UP)-250110

${ }^{2}$ Divison of Soil Physics,ICAR-Indian Institute of Soil Science,Bhopal(MP)-462038

${ }^{3}$ Department of Agrometeorology, College of Agriculture, GBPUA\&T, Pantnagar-263145

*Corresponding author:smita4gupta@gmail.com

\begin{abstract}
Twenty one years (1992-2013) of weather data and yield data of wheat and mustard for 10 districts of western Uttar Pradesh were used to develop yield prediction model. The models were validated with 2014 and 2015 data set. The results revealed that pre harvest forecasting model had $R^{2}$ values ranging between 22 and 81 per cent for wheat crop and between 26 and 87 per cent for mustard in the different districts. During both the years of validation the observed yields were in good agreement with forecasted yields for wheat as well as mustard.
\end{abstract}

Key words : Forecast, wheat, mustard, validate, model

Climate is a primary determinant of agricultural production and changes in climate would likely to have devastating effect on agriculture. Uttar Pradesh ranks first in area $(36.58 \%)$ and production $(36.27 \%)$ of wheat in the country. Most of the production comes from the areas of the Ganga-Yamuna Doab and the Rohilkhand plains. Rapeseedmustard is the second most important edible oilseed after groundnut sharing 27.8 per cent in the India's oilseed economy, (Sekhawat, 2012). Rajasthan is the largest producing state followed by Uttar Pradesh, Haryana, Madhya Pradesh, Gujarat, West Bengal, Bihar and Punjab etc (Anonymous, 2009).

Considering the importance of wheat and mustard crop a attempt was made to develop pre harvest yield forecasting models, in the selected districts of western Uttar Pradesh.

\section{MATERIAL AND METHODS}

The long period (1992-2015) yield data of wheat and mustard crop were collected from website of Directorate of Economics and Statistics, Department of Agricultural and Coperation, Ministry of Agriculture, Govt.of India(http:// eands.dacnet.nic.in/). The standard meteorological week (SMW) wise weather data from $40^{\text {th }}$ to $7^{\text {th }}$ were used to develop regression models for 10 districts (Meerut, Muzafanagar, Saharanpur, Barielly, Bijnor, Moradabad, Pilibhit, Rampur, Aligarh, Badaun) for wheat crop and from $40^{\text {th }}$ to $4^{\text {th }} \mathrm{SMW}$ data were used to develop models for six districts of western Uttar Pradesh (Aligarh, Badaun, Bulandshahar, Moradabad, Sahjahnpur and Rampur) for mustard following methodology described by Ghosh et al., (2014).The models were validated with observed yield data of 2014 and 2015. The variables used in the study were rainfall $(\mathrm{RF}, \mathrm{mm})$, maximum $\left(\mathrm{T}_{\max }\right)$ and minimum $\left(\mathrm{T}_{\min }\right)$ temperature $\left({ }^{\circ} \mathrm{C}\right)$, morning relative humidity $(\mathrm{RH} \mathrm{I}, \%)$ and afternoon relative humidity (RH II, \%). Different weather indices were generated using weekly values of weather parameters and their weighted values using correlation coefficient (Table 1).

\section{RESULTS AND DISSCUSSION}

\section{Wheat yield forecasting}

The wheat yield prediction model developed for 10 districts of western Uttar Pradesh (Table 2) show that minimum temperature (Tmin) is the most important parameters common in all the models. The coefficient of determination $R^{2}$ ranged between 0.30 to 0.81 which were significant at $P$ $=0.05$. During validation (Table 3 ), the percent error between observed and predicted were less than 10 implying that these models can be used for predicting the wheat yield in these 10 districts of west U.P. Similar work for eastern Uttar Pradesh has been reported by Singh et al. (2014).

\section{Mustard yield forecasting}

The models developed for yield forecasting of mustard in six districts of western U.P.(Table 4) show that the $\mathrm{R}^{2}$ 
Table1:Weather indices used in models using composite weather variables

\begin{tabular}{|c|c|c|c|c|c|c|c|c|c|c|}
\hline \multirow{2}{*}{$\begin{array}{l}\text { Weather } \\
\text { parameter }\end{array}$} & \multicolumn{5}{|c|}{ Simple weather indices } & \multicolumn{5}{|c|}{ Weighted weather indices } \\
\hline & $\mathrm{T} \max$ & $\mathrm{T} \min$ & $\mathrm{R} / \mathrm{F}$ & $\mathrm{RH}(\mathrm{I})$ & RH(II) & $\overline{T \max }$ & Tmin & $\mathrm{R} / \mathrm{F}$ & $\mathrm{RH}(\mathrm{I})$ & RH(II) \\
\hline $\mathrm{T} \max$ & $\mathrm{Z} 10$ & & & & & $\mathrm{Z} 11$ & & & & \\
\hline T min & $\mathrm{Z} 20$ & $\mathrm{Z} 20$ & & & & $\mathrm{Z} 21$ & $\mathrm{Z} 21$ & & & \\
\hline $\mathrm{R} / \mathrm{F}$ & $\mathrm{Z30}$ & $\mathrm{Z} 30$ & $\mathrm{Z30}$ & & & $\mathrm{Z} 31$ & $\mathrm{Z} 31$ & $\mathrm{Z} 31$ & & \\
\hline RH(I) & $\mathrm{Z} 40$ & $\mathrm{Z} 40$ & $\mathrm{Z} 40$ & $\mathrm{Z} 40$ & & Z41 & Z41 & $\mathrm{Z} 41$ & Z41 & \\
\hline $\mathrm{RH}(\mathrm{II})$ & $\mathrm{Z} 50$ & $\mathrm{Z} 50$ & $\mathrm{Z} 50$ & $\mathrm{Z} 50$ & $\mathrm{Z} 50$ & Z51 & $\mathrm{Z} 51$ & $\mathrm{Z} 51$ & $\mathrm{Z} 51$ & Z51 \\
\hline
\end{tabular}

Table 2 : Pre-harvest yield forecast model (F3 stage) of wheat crop for different districts of Western Uttar Pradesh

\begin{tabular}{llllll}
\hline S.No. & District & Equation & $\mathrm{R}^{2}$ & $\mathrm{~F}$ & \multicolumn{2}{c}{ Std error } \\
\hline 1 & Meerut & $\mathrm{Y}=6118.23+(19.76 * \mathrm{Z} 11)+(18.46 *$ time $)+(-.089 * \mathrm{Z} 230)+(.068 * \mathrm{Z} 241)$ & 0.68 & 42.5 & 165.2 \\
2 & Muzaffarnagar & $\mathrm{Y}=1672.00+(7.34 * \mathrm{Z} 41)+(.131 * \mathrm{Z} 241)$ & 0.58 & 27.8 & 136.7 \\
3 & Saharanpur & $\mathrm{Y}=853.31+(-168 * \mathrm{Z} 131)+(2.48 * \mathrm{Z} 41)$ & 0.64 & 36.5 & 153.8 \\
4 & Bareilly & $\mathrm{Y}=3245.65+(49.76 *$ time $)+(-0.27 * \mathrm{Z} 240)$ & 0.81 & 89.7 & 136.7 \\
5 & Bijnor & $\mathrm{Y}=3103.54+(38.67 *$ time $)+(-2.35 * \mathrm{Z} 20)$ & 0.75 & 61.8 & 122.9 \\
6 & Moradabad & $\mathrm{Y}=2787.19+(.308 * \mathrm{Z} 151)+(19.45 *$ time $)+(0.83 * \mathrm{Z} 241)$ & 0.46 & 17.6 & 155.6 \\
7 & Pilibhit & $\mathrm{Y}=2588.23+(53.47 *$ time $)$ & 0.68 & 44.1 & 239.6 \\
8 & Rampur & $\mathrm{Y}=2672.27+(8.44 * \mathrm{Z} 11)+(.04 * \mathrm{Z} 250)$ & 0.3 & 8.68 & 186.1 \\
9 & Aligarh & $\mathrm{Y}=2303.49+(30.30 *$ time $)+(6.23 * \mathrm{Z} 31)+(0.21 * \mathrm{Z} 151)$ & 0.41 & 14.3 & 205.1 \\
10 & Badaun & $\mathrm{Y}=3207.77+(33.37 *$ time $)+(.30 * \mathrm{Z} 251)+(-.075 * \mathrm{Z} 230)+(-2.74 * \mathrm{Z} 20)$ & 0.65 & 38.81 & 213.6 \\
\hline
\end{tabular}

Table 3: Observed and forecasted $\left(\mathrm{kg} \mathrm{ha}^{-1}\right)$ yield of wheat crop in 2014 and 2015 for various districts of Western Uttar Pradesh

\begin{tabular}{llrrrrrrr}
\hline & & \multicolumn{3}{c}{2014} & & \multicolumn{2}{c}{2015} \\
\cline { 3 - 4 } S.No. & Districts & Observed & Predicted & Error \% & & Observed & Predicted & Error \% \\
\hline 1 & Aligarh & 3712 & 3603 & 3.7 & & 3691 & 3495 & 6.8 \\
2 & Meerut & 4216 & 4059 & 4.7 & & 4254 & 3964 & 7.4 \\
3 & Saharanpur & 3521 & 3171 & 9.9 & 3421 & 3085 & 9.8 \\
4 & Bijnor & 2703 & 3197 & 3.9 & & 2889 & 3281 & 2.1 \\
5 & Moradabad & 2830 & 3131 & -1.81 & & 2997 & 3336 & -1.31 \\
6 & Pilibhit & 3871 & 3818 & -10.2 & & 3759 & 3872 & -10.6 \\
7 & Rampur & 3316 & 3042 & 1.3 & & 3357 & 3279 & -3.0 \\
8 & Bareilly & 3672 & 3527 & 8.2 & & 3704 & 3624 & 2.3 \\
9 & Muzaffarnagar & 3809 & 3627 & 2.9 & & 3612 & 3343 & 5.2 \\
10 & Badun & 3768 & 3465 & 8.00 & & 3747 & 3419 & 8.71 \\
\hline
\end{tabular}

value ranged between 0.26 to 0.87 in different districts which were significant at $\mathrm{P}=0.5$. Similar to the wheat crop the minimum temperature was common contributing factors in models for mustard crop in most of the districts under study. During validation period 2014 and 2015 the performance of models were quite satisfactory as the percent errors were less than 10 in all districts(Table 5).Hence these models can be used to forecast mustard yield in the districts under study.

\section{ACKNOWLEDGMENTS}

The authors are thankful to India Meteorological 
Table 4: Pre-harvest yield forecast model (F3 stage) of Mustard crop for different districts of Western Uttar Pradesh

\begin{tabular}{llllll}
\hline S.No. & District & Equation & $\mathrm{R}^{2}$ & $\mathrm{~F}$ & Std error \\
\hline 1 & Aligarh & $\mathrm{Y}=849.649+(32.12 *$ time $)$ & 0.50 & 20.03 & 213.57 \\
2 & Budaun & $\mathrm{Y}=260.92+(39.85 * \mathrm{Z} 11)+(.12 * \mathrm{Z} 241)$ & 0.40 & 13.62 & 81.32 \\
3 & Bulandshar & $\mathrm{Y}=1190.9+(10.8 *$ time $)+(0.5 * \mathrm{Z} 121)+(38.5 * \mathrm{Z} 11)$ & 0.67 & 40.75 & 106.42 \\
4 & Moradabad & $\mathrm{Y}=-861.26+(.08 * \mathrm{Z} 141)+(2.69 * \mathrm{Z} 121)+(-53.34 * \mathrm{Z} 21)$ & 0.87 & 66.4 & 138.4 \\
5 & Rampur & $\mathrm{Y}=1805.3+(.71 * \mathrm{Z} 121)$ & 0.43 & 15.2 & 97.30 \\
6 & Shahjanpur & $\mathrm{Y}=1056.6+(171.8 * \mathrm{Z} 11)+(.07 * \mathrm{Z} 451)+(.02 * \mathrm{Z} 340)$ & 0.26 & 7.10 & 130.16 \\
\hline
\end{tabular}

Table 5: Observed and forecasted $\left(\mathrm{kgha}^{-1}\right)$ yield of mustard crop in 2014 and 2015 for various districts of western Uttar Pradesh

\begin{tabular}{llrrrrrrr}
\hline & & \multicolumn{3}{c}{2014} & & \multicolumn{2}{c}{2015} \\
\cline { 3 - 4 } \cline { 7 - 9 } S.No. & Districts & Observed & Predicted & Error \% & & Observed & Predicted & Error \% \\
\hline 1 & Aligarh & 1455 & 4588 & -9.0 & & 1597 & 1621 & -1.4 \\
2 & Budaun & 611 & 616 & 1.5 & & 590 & 598 & 4.8 \\
3 & Bulandshar & 1376 & 1258 & 8.7 & & 1319 & 1217 & 9.8 \\
4 & Moradabad & 1153 & 1164 & -1.0 & & 1076 & 1212 & -1.2 \\
5 & Rampur & 1132 & 1029 & 9.0 & & 1046 & 1055 & 8.4 \\
6 & Shahjanpur & 908 & 902 & 0.6 & & 971 & 930 & 1.6 \\
\hline
\end{tabular}

Department, Ministry of Earth Sciences for financial assistance.

\section{REFERENCES}

Anonymus (2009). Directorate of Oilseeds Development, Hyderabad. http: //www.dac.nic.in/ oilseed/gapy February 6, (2009).

Ghosh, K., Balasubramanian, R,.Bandopadhyay, S., Chattopadhyay, N., Singh, K. and Rathore, L.S. (2014).
Development of crop yield forecast models under FASAL- a case study of kharif rice in West Bengal. $J$. Agrometeorol., 16(1): 1-8.

Singh,R.S.,Patel,C.,Yadav,M.K.,Singh,K.K.(2014).Yield forecasting of rice and wheat crops for eastern Uttar Pradesh,J.Agrometeorol.,16(2):199-202.

Website of Directorate of Economics and Statistics, Department of Agricultural and Cooperation, Ministry of Agriculture, Govt. of India (http://eands.dacnet.nic.in/). 